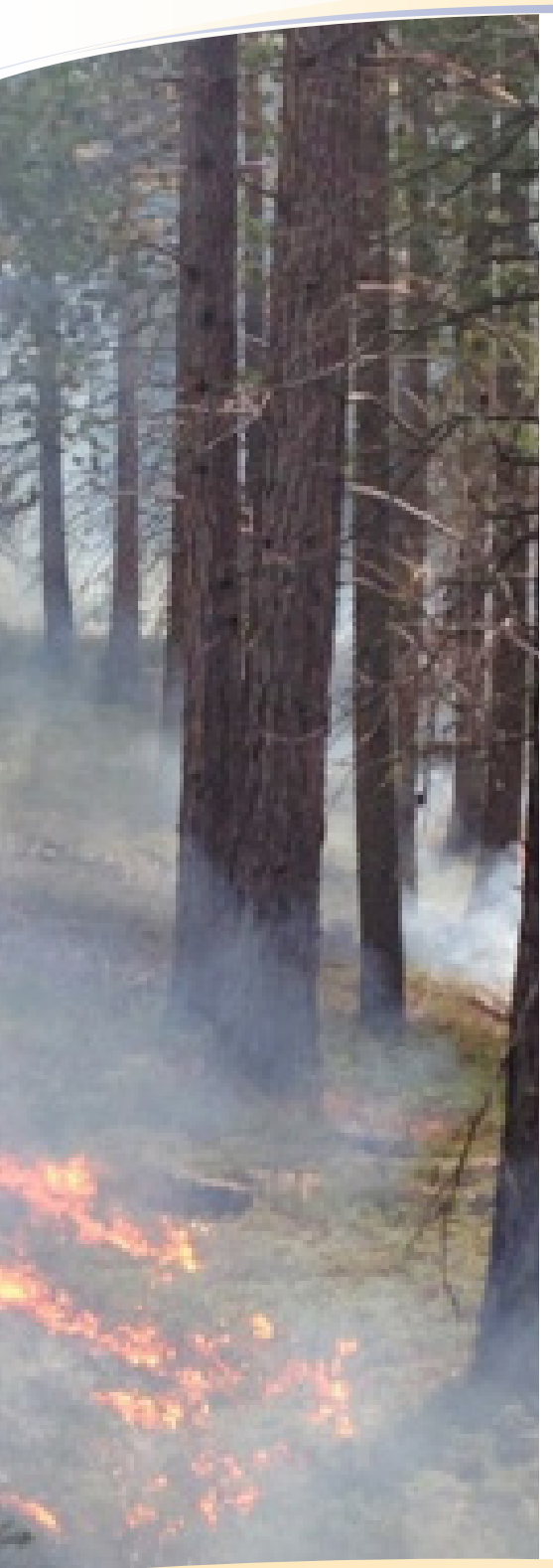

\title{
Recovering from Wildfire: A Guide for California's Forest Landowners
}

\author{
What ShOULD I Do Now?
}

$\Lambda$ s a a forest landowner, you will eventually face the inevitable: wildfire.

No matter how many acres have burned on your property, you are left wondering, "What should I do now?" After the fire is out, it is time to assess the impact of the fire and make some decisions. Wildfires typically have a range of impacts, many of which can be damaging to trees and property. However, when wildfires burn at lower intensities, they often have fewer negative impacts and may actually improve the long-term health of the forest. Understanding the range of impacts on your property can help you decide where and when to take action to protect your land from further impacts and to recoup losses.

This publication discusses issues that forest landowners should consider following a wildfire in their forest, including how to assess fire impacts, protect valuable property from damage due to erosion, where to go for help and financial assistance, how to salvage dead trees or replant on your land, and how to claim a casualty loss on your tax return.

\section{UNDERSTANDING THE FIRE's EFFECTS}

Fire is a dynamic process that typically burns in a mosaic pattern with a broad range of fire severities. Fire severity is the magnitude of ecological change from prefire conditions, usually described in terms of the amount of live biomass that was killed. In forested ecosystems, the amount of change can be understood as the amount of mortality to the overstory trees, which affects live tree volume and canopy cover. Fire severity is commonly grouped into three classes: low, moderate, and high. 
It is important to identify the fire's effects on all sections of your property because, despite the common initial impression that an individual fire is "severe," all wildfires include a variety of severities within their perimeter, and these different severity classes may be present on your property. Understanding variations in the distribution of severity across the landscape is important because it not only describes the current, immediate effects, but it can also help predict likely longer-term changes. The generalizations about fire's effects listed here apply mainly to forested ecosystems in California, with emphasis on yellow pine and mixed-conifer forests, and it is important to recall that different forest types within California respond somewhat differently. Despite these differences, much of the overview of potential ecological effects and landowner concerns in relation to severity classes can be applied to other forested landscapes.

\section{Low-Severity Fire}

Low-severity fire burns primarily on the forest floor and causes very little overstory tree mortality (fig. 1).

Ecological effects. Although there is considerable variation across the diverse forest types in California, mixed conifer is the most widely distributed type (and includes ponderosa pine, grey pine, sugar pine, white fir, Jeffrey pine, Douglas-fir, and black oak), and it is well adapted to frequent, low- to moderate-severity fire (table 1). Many of the dominant mature trees survive when fires burn with a mixture of low and moderate severity, which in turn can promote the growth of other plants. When some trees are killed, more light reaches the forest floor, and more soil nutrients and soil moisture are available to native species of grasses and flowering plants and to the remaining trees, which can increase their growth and vigor. Many of the species that occur in California's forests are well adapted to fire and can flourish after lower-severity fires.

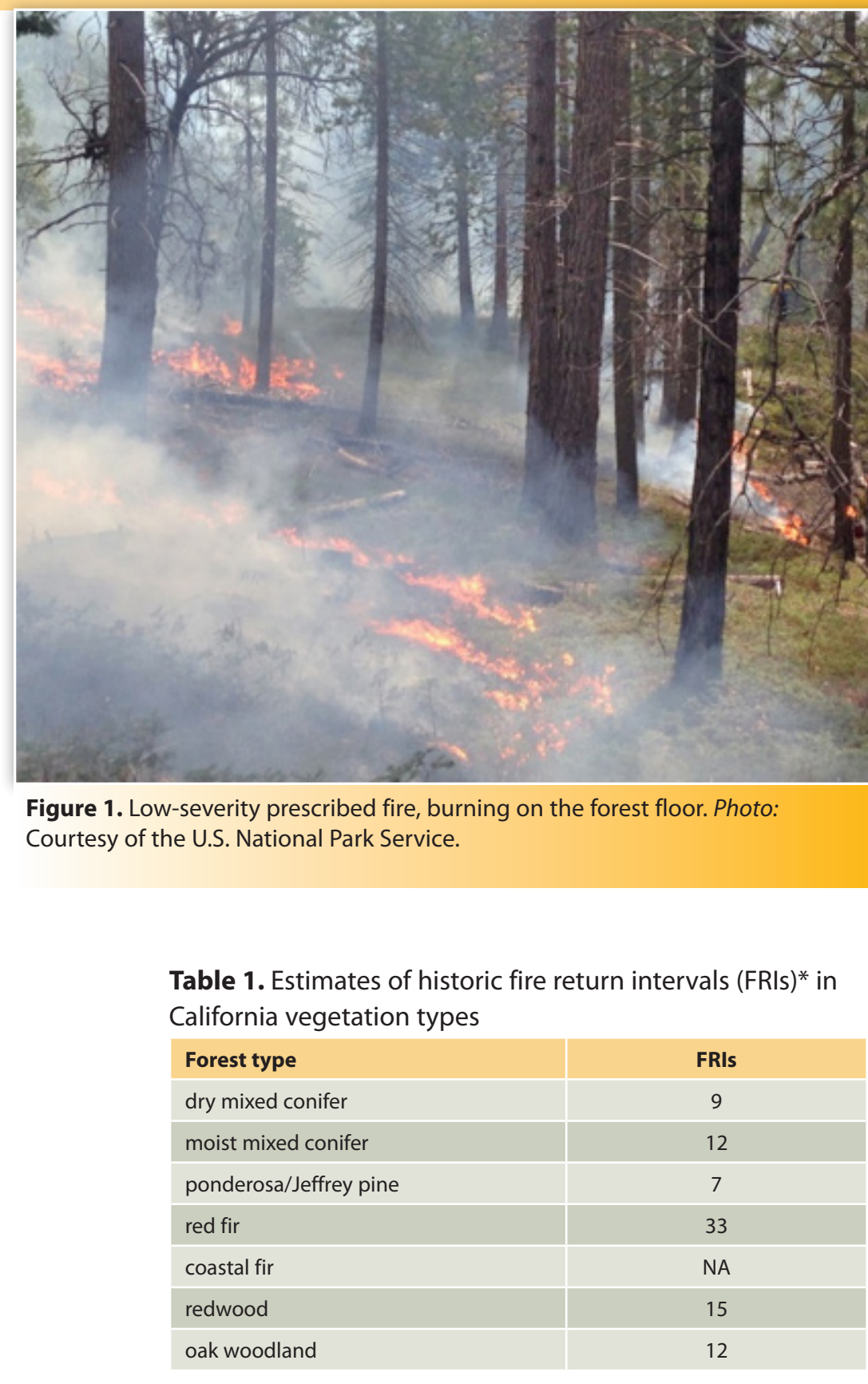

Note: ${ }^{*}$ Historic fire return interval is defined as the average number of years between fires. Averages are determined through tree ring studies. 


\section{The historic role of fire in California's mixed-conifer forests: How do we know what we know?}

Scientists use many lines of evidence to understand the historic role of fire in California's forests. These include

\section{Tree ring studies}

- Fire scars on tree rings show when fires occurred.

\section{Historical accounts}

- Native American oral histories describe "open, parklike forests," frequent fire, and the use of fire to maintain valuable plants for food and basket weaving.

- Early settlers recorded accounts of fires.

- Charcoal deposits in lakebeds can give clues to past fire frequency on very long time scales.

Species adaptations

- The dominant tree species (ponderosa pine, sugar pine) have adaptations that suggest an evolutionary history of frequent fire. For example, many of the common pine species have thick bark that can withstand lower-intensity fires. They also self-prune their lower branches so fire does not enter into the canopy, and their seedlings thrive in small forest openings with charred litter. Serotinous cones, which require heat from high-severity fires to open, are rare.
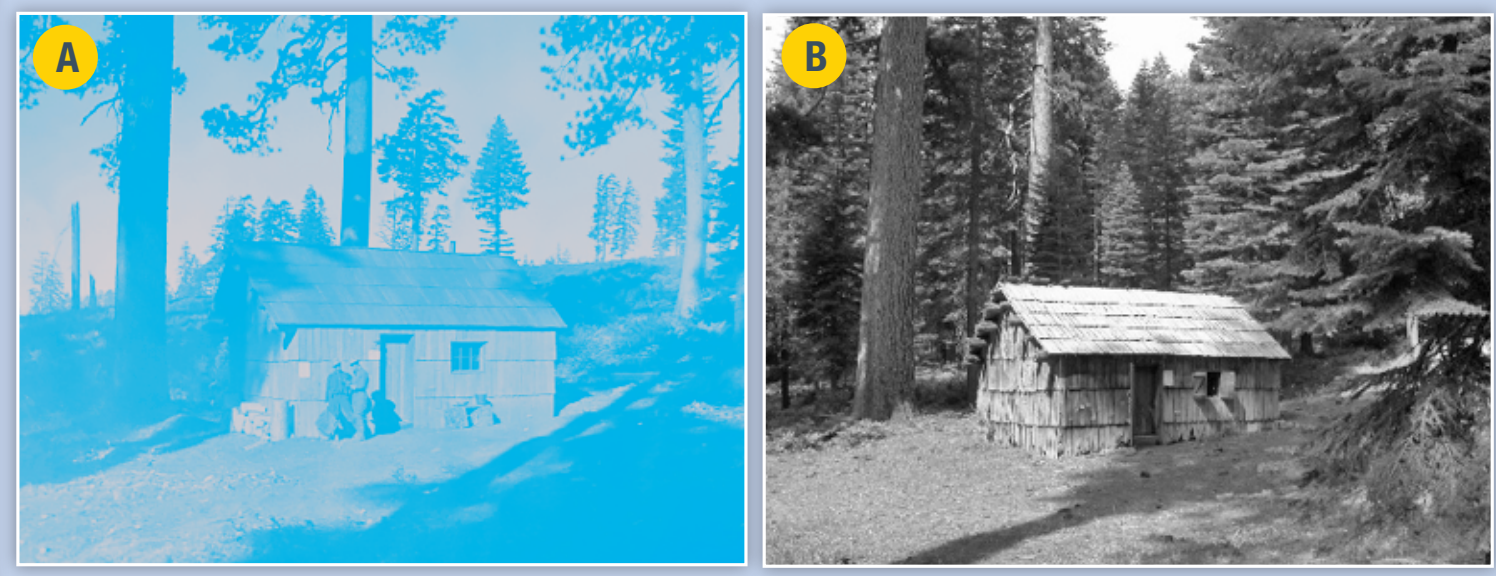

Figure 2. A) Guard station in the Plumas National Forest in 1911. B) Same location in 2005. Vegetation has filled in as a result of fire suppression. Photos: A) Courtesy of U.S. Forest Service, Plumas National Forest; B) Ryan Tompkins and Jason Moghaddas.
Low-severity fire can also help promote the persistence of the dominant tree species on a site. In oak woodlands, oaks that are top-killed in a fire will generally sprout from their roots and survive. More importantly, the temporary reduction in cover by grasses and flowering plants after lowto moderate-severity fire can reduce competing grasses and allow new oak seedlings to establish. Frequent fires also kill young conifers encroaching on the site, which is important for long-term maintenance of oaks on a site.

In mixed-conifer forests, low-severity fire can help promote pine re-establishment. In forests where fire has been excluded, the forests have become denser and the sunloving, fire-tolerant pines (ponderosa, sugar) have become outnumbered by fire-intolerant species (incense cedar, white fir) that can grow in dense, shady forests. Low-severity fire can also kill shade-tolerant trees in the understory and increase the sun infiltration to the forest floor. It also reduces surface fuels, which then allows pines to re-establish, helping to maintain these fire-adapted trees across the landscape. In addition, low-severity fires that burn primarily on the forest floor can help reduce the risk of severe fire in the future by thinning dense stands and reducing the accumulated surface fuels. For these reasons, lower-severity fire can benefit forest health.

Landowner concerns. After most low-severity fires, many of the mature overstory trees should survive, allowing for continuity and regeneration of the forest as well as hillslope stability. However, individual trees that were injured or stressed during the fire may be more likely to be attacked and later die from bark beetles or other stressors. Needles and leaves continue to fall from the trees in autumn and act as a natural mulch by covering the soil and reducing soil erosion risk. Needles scorched by the fire can also fall and have this positive effect. Herbaceous vegetation and shrubs will re-establish from unburned seeds in the soil or by sprouting from surviving roots within a few years, or sooner in moist areas. 
Figure 3. Low-severity burn (center of photo): trees remain green and have live foliage after the fire, which burned along the ground. In areas of moderate severity (foreground and background), small patches of trees have been killed and some green live trees remain. Photo: Courtesy of

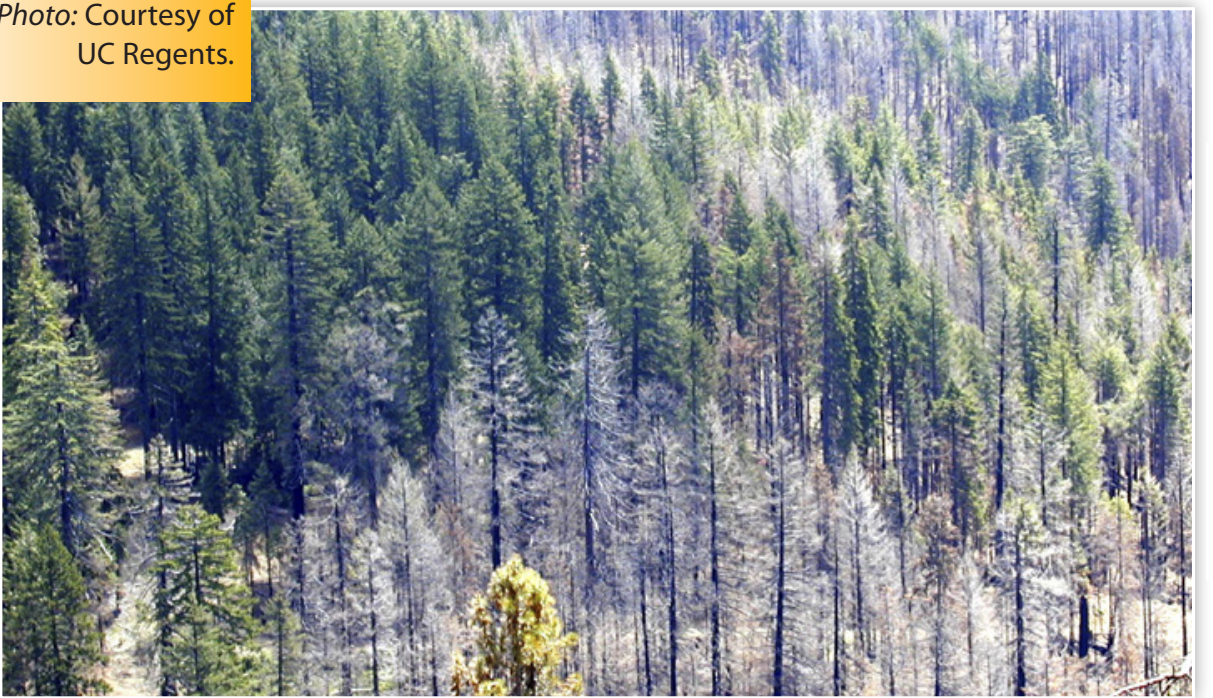

higher-severity fire may experience only moderate ecological impacts, but owners could face severe economic impacts in terms of lost timber revenue, standing snag hazards, and future fuel conditions. To determine the economic and scenic impacts that result from the forest mortality on your property, you will need to consider how much live vegetation was lost over how much area (i.e., the fire severity patterns across your property) and how that fits with your management goals (such as timber harvest or wildlife habitat) and proximity to values at risk (i.e., standing snags near structures). More information on how to evaluate these potential hazards appears in the sections that follow.

\section{High-Severity Fire}

High-severity fire is defined as having complete or near complete mortality occurring across large, contiguous areas (or patches).

Ecological effects. Because the mixed-conifer forests of the Sierra Nevada historically burned relatively frequently at low and moderate severity, high-severity areas were spatially limited. The amount and patch size of high-severity fire that occurred prior to fire exclusion is difficult to quantify with certainty. Some research, as well as the adaptations of the dominant conifer species, suggest that highseverity patches occurred on the order of up to a few hundred acres historically (fig. 4). This created a mosaic across the landscape, where and subsequently describe the ecological effects of that vegetation

loss. These categories do not reflect how severely you may be impacted as a landowner. For example, some areas burned by
Moderate-severity areas experience more variable effects and greater mortality (fig. 3). In these areas, the fire burns on the forest floor in variability is important for many wildlife species that specialize in

Landowner concerns. The higher tree mortality in moderateseverity areas may increase the need to consider removing individual dead or damaged trees for safety or economic reasons. It is important to understand that the severity classes described here (low, moderate, high) really represent a continuous percentage of live vegetation lost

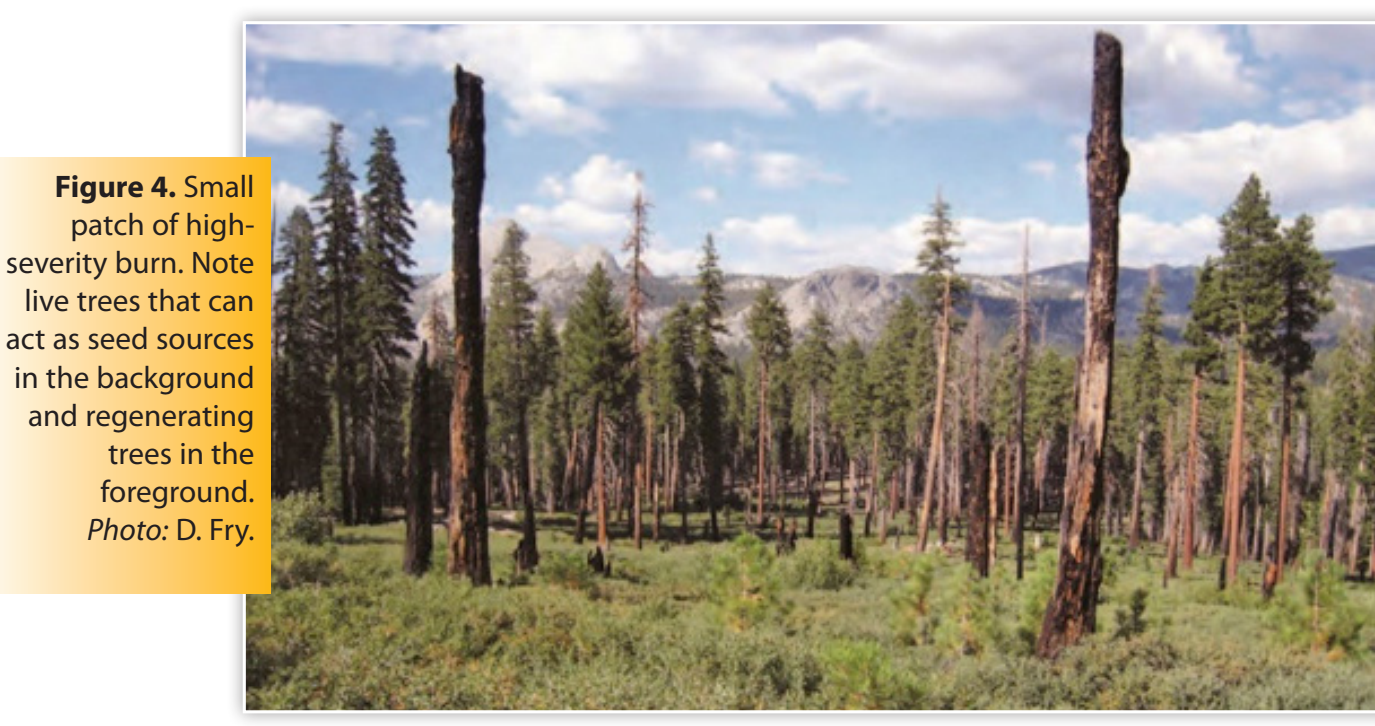


Figure 5. Large patch of high-severity burn from the 2014 King fire. Photo: B. Estes. repeated fires burned in a patchwork quilt of severities, but their frequency generally kept severity quite low overall. Historically, small patches of high-severity fire had an important ecological role, providing standing and fallen snags for wildlife habitat and nutrient inputs to the soil. Species such as the black-backed woodpecker require the blackened snag habitat created by severe fire, and the shrub vegetation that dominates these landscapes for many years can support a different set of plant and animal species than is found in forested habitats. In this way, small patches of high severity increase diversity across the landscape.

However, there have been large increases in the amount of contiguous, severely burned areas in recent decades, which are now occurring on the order of thousands of acres (fig. 5). These increases are a result of the fuel buildup that has occurred due to fire exclusion, changes in both timber harvest and grazing practices, and climate change. The large size of high-severity patches, which have become more common in California mixedconifer forests in recent decades, often has undesirable ecological

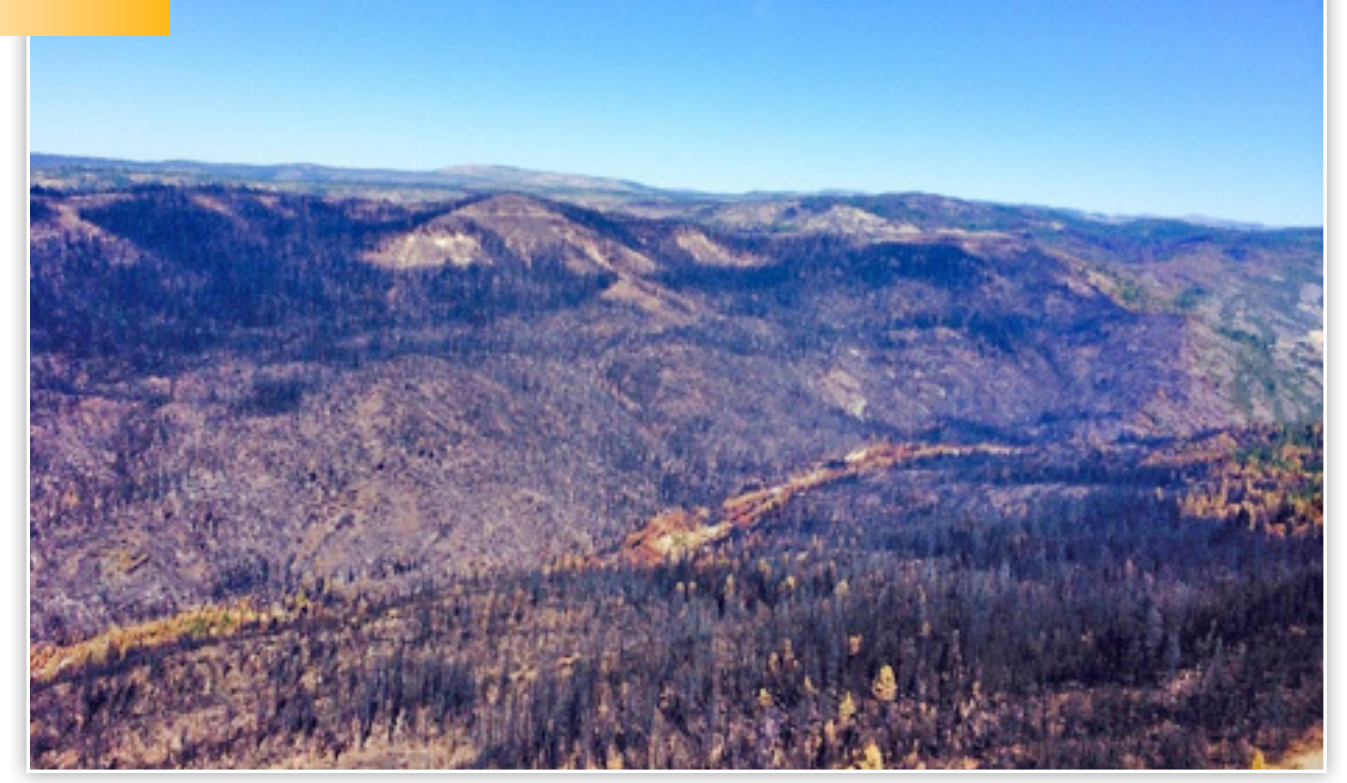

effects. These patches can lead to the large-scale loss of forested wildlife habitats, which are important to many common as well as declining wildlife species such as the Pacific fisher and the California spotted owl. They can also impact the soil so severely that seeds and nutrients stored in the soil are lost. The loss of forest litter (fresh and decayed needles, leaves, and branches on the forest floor) can increase soil erosion, which has significant effects on waterways and streams. One of the biggest concerns is that, in large patches where all trees have been killed by the fire, natural conifer forest regeneration may be delayed because of the increased distances to live tree seed sources. In addition, there is often a very vigorous native shrub response, since existing shrubs can sprout from their roots after being top-killed, and many new shrubs can germinate because the seeds in the soil are often stimulated by wildfire. These dense shrubs compete with conifer seedlings for soil and light, and so they may crowd out naturally occurring seedlings. Long-term, large patches of high severity can contribute to high fuel loads when all of the dead trees fall. When the area burns again, this can cause excessive soil heating.

Landowner concerns. High-severity fire results in the greatest change to forests, and it raises the greatest number of concerns for the private landowner. Most broadly, it can include the loss of timber as well as the scenic and recreational value of forests. It can also create serious hazards, including dead trees, landslides, damage to infrastructure, soil erosion, and flooding. When the dead trees fall and add to the surface fuel, they can cause control problems for firefighters. When the downed trees accumulate among the tall shrubs that regenerate, they can burn severely in the next fire. Although smaller patches of high severity do not raise ecological concerns, they may require postfire action if they do not align with management goals or if they occur near infrastructure. It is helpful to map the variety of effects on your land, with specific emphasis on areas that have a contiguous mortality of mature trees, in order to evaluate postfire management options. In the next section, we outline ways to assess the state of your land and the common mitigation measures available to address these issues. 


\section{Postfire Management Concerns: Assessments and Mitigation Options}

Decisions about mitigation actions will likely focus on the areas of greatest change, where tree mortality is the highest. However, there is an immediate need to assess safety more broadly than just from falling trees, including the potential for increased flooding that may result in road damage, plugged culverts, or damage to homes. Other decisions will depend on your longer-term objectives for your property. In this section, we review some of the major areas of concern in burned forests for the private landowner: revegetation, soil erosion, roads, and dead trees. For each topic area, we provide an overview of the concern, information on how to assess fire effects on your property, and commonly applied mitigation options.

\section{Revegetation}

Whether or not to actively revegetate a forested landscape depends on the dominant vegetation type (oak woodlands, montane shrub, conifer forest, etc.), the fire severity, and the landowner's objectives. Different plants respond to fire differently, and much of this depends on their growth and reproduction characteristics. What follows is a brief summary of how flowering plants and grasses, as well as shrubs and trees, may respond to fire. Within each of these categories there can be a great deal of variation by individual species. This discussion will attempt to paint a broad overview and to outline the characteristics that will be important for postfire management decision-making.

\section{Vegetation Assessment}

Flowering plants and grasses

Many flowering plants and grasses have long-lived seed banks in the soil or mechanisms that enable them to sprout from their roots after fire. In some places, the postfire response of these plants can be quite vigorous, as the death of the larger trees has freed up resources for them to capture. Some plant seeds depend on fire to germinate, and some species can only grow in the conditions that occur during the first few years following a fire. In areas where the soil experienced very high burn severity, the fire may have killed

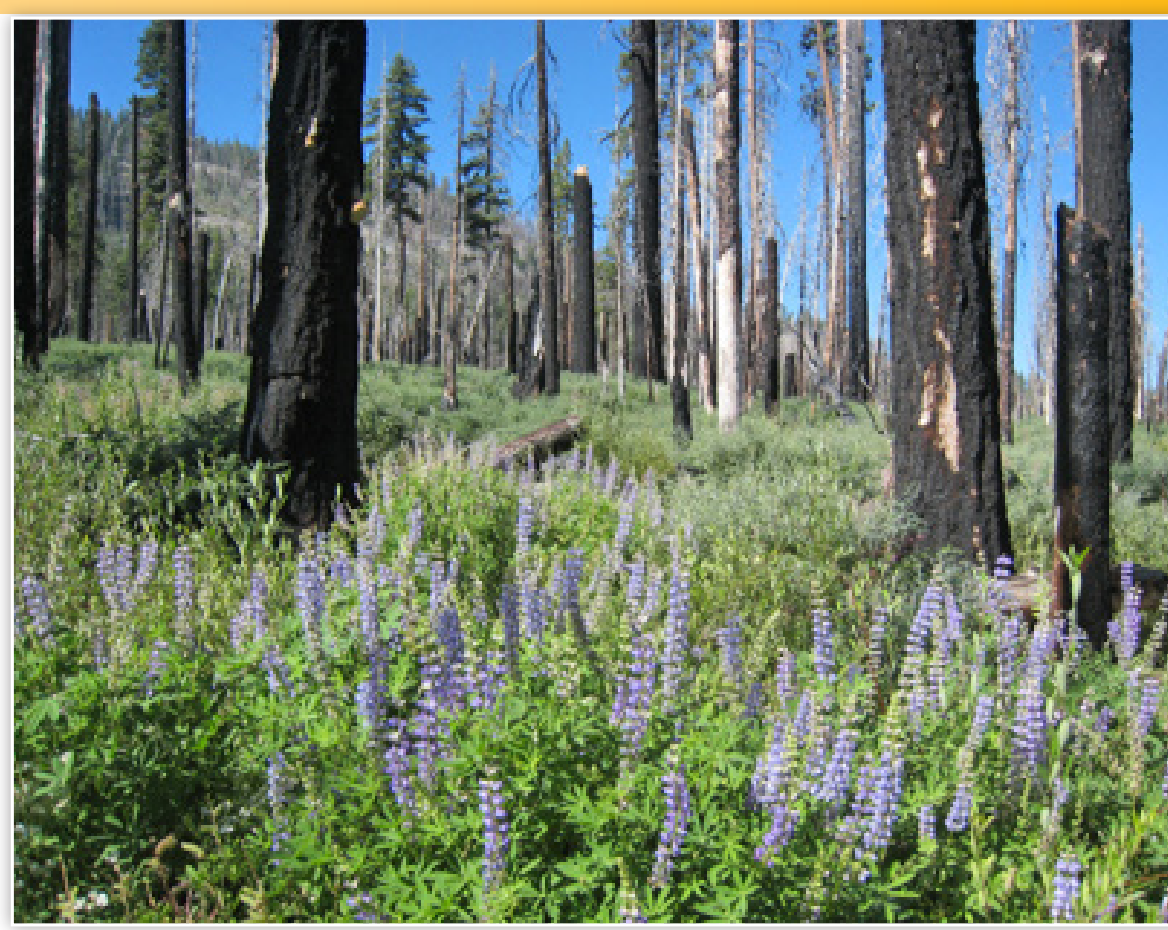

Figure 6. Postfire herbaceous plant response. Photo: K. Wilkin.

many of the seeds and nutrients stored in the soil. Although this can delay the regeneration of these plants, generally they recover within a few years (fig. 6). In addition, it is important to consider the land and its productivity. For example, very exposed sites with rocky soil may not be able to support high cover of flowering plants and grasses, irrespective of the fire. In contrast, flowering plants in riparian areas are expected to recover quickly, given the higher moisture availability.

In some cases, fire has been associated with the spread of non-native species, allowing invasive plants to take advantage of the open space and high light conditions. These generally occur in high-severity areas that had invasive weeds present before the fire, or where there is a nearby population that can act as a seed source. Invasions can also occur in areas where heavy equipment and firefighting activities took place, because the equipment acts as a vector to introduce invasive seeds. In the 1 to 2 years after a fire, field surveys should be done to identify the presence of problematic non-native species. Not all new species seen after a 
fire are non-native, and not all non-native species are highly invasive and therefore problematic. To determine if you have any problematic invasive weeds, consult the resources listed in the reference section at the end of this publication.

\section{Shrubs}

Many shrub species thrive in a postfire environment. Many can sprout after fire, and many have long-lived seeds in the soil, some of which are actually stimulated by fire. Thick growth of these shrubs after a severe forest fire can promote another high-severity fire in the future, especially where large-diameter surface fuels have developed from burned trees falling to the ground.

\section{Trees}

Evaluating which trees are dead or likely to die in the near future due to damage from a fire can be difficult, depending on the species and its reproductive strategies. Not all trees will die in the first year, and fire-related mortality can continue for 2 to 6 years following fire.

The primary clues to look for include damage to the cambium, an inner layer of tissue between the bark and the wood that transports water and nutrients, as well as needle or leaf consumption by the fire. Here we review how these types of injuries affect the two dominant tree types in California forests, oaks and conifers, and explain how their characteristics affect survival and reproduction postfire.

Oaks with a completely scorched, dead canopy may be able to produce new leaves in the following growing season if the cambium is not charred around the entire circumference of the base (fig. 7). Even a small percentage of intact cambium can allow the oak to survive, albeit at reduced vigor. When the cambium is damaged all the way around the base, it is considered "top-killed" but will most likely sprout from the roots the following growing season (fig. 8).

The dominant conifer species in California include numerous shade-intolerant pines (such as ponderosa pine, sugar pine, Jeffrey pine, Coulter pine, and lodgepole) as well as numerous more shadetolerant species (including incense cedar, white fir, Douglas-fir, and coast redwood). Most conifers, except coast redwood, do not sprout from underground roots. Therefore, an individual tree with totally consumed needles (torched trees) or severe damage to the cambium is dead, because it has lost its ability to photosynthesize and transport water and nutrients. Completely scorched trees (trees that were damaged by heat and whose needles were not burned but are dead and brown) generally do not survive, though in rarer cases these trees can flush new growth and survive. It is also common
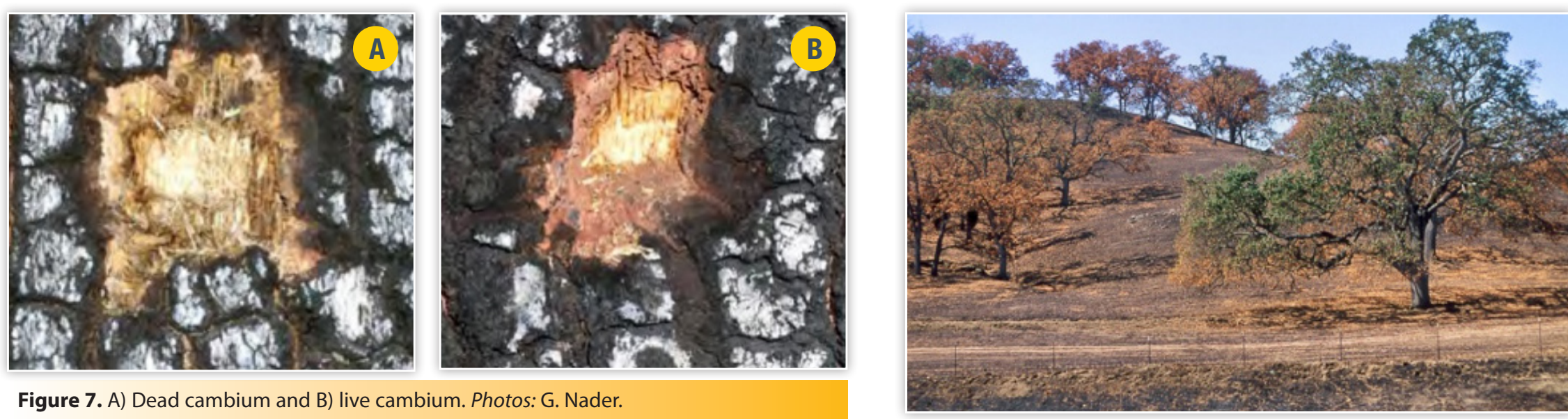

Figure 8. Burned oak woodland. Many of the trees with dead crowns survive by sprouting from their crown or base. Photo: Courtesy of UC Regents.

Figure 7. A) Dead cambium and B) live cambium. Photos: G. Nader. 
for many trees to sustain intermediate levels of damage, where only part of the canopy is scorched or torched, or where the cambium has lower levels of damage. In these cases, survival and mortality are far less certain. Some will survive, but this type of damage can also weaken a tree and increase its susceptibility to later mortality from other stressors, including insect attack.

Because most conifers do not have the capacity to sprout after fire, they can only persist on site after severe fire if new individuals germinate from seed. A few sparsely distributed species (such as giant sequoia, as well as bishop and knobcone pine) have serotinous cones, or cones that only open during the heat from fire. This trait results in seeds that survive and germinate on-site immediately after a severe fire, even if the parent tree was killed. However, these species are relatively rare on the California landscape; the dominant conifers do not have serotinous cones or long-lived seed banks in the soil. Conifer regeneration postfire is therefore primarily limited by the proximity of live trees that can provide seeds. Seed dispersal distances vary by species, but for many of the common conifers in California, seed dispersal is thought to be limited to one to two times the height of the seed tree. In larger high-severity patches, the distance to live conifer tree seed sources is greatly increased, which could result in significant delays in natural reforestation of these species. The lack of seed sources means that the postfire landscape may be dominated by shrub species instead of conifers for at least a decade, and often for several decades.

\section{Vegetation Mitigation Options}

Planting or seeding of flowering plants, grasses, and shrubs is usually not necessary after a fire. Sometimes when the soil burns severely, it can reduce the existing seed bank and result in low cover and diversity in the first year postfire. However, even these areas usually recover on their own within a couple of years. It was common in the past to seed grasses and flowering plants in an attempt to quickly increase cover and diversity. However, recent research has shown that seeding is generally not any more effective than letting the area recover naturally; and given the risk of introducing invasive species (even with certified weed-free seed mixes), it is generally not recommended. Where invasive species are detected, a combination of hand-pulling and herbicide may be required to remove them from the landscape, depending on the species in question (see the references section for more information on treatment options).

For tree species, top-killed oaks are likely to persist in the long-term by sprouting from the base. Seedlings are less likely to germinate after fire in high-severity areas, because the acorns are often consumed by fire. Where oaks do germinate or survive, seedlings can be fenced to help protect them from browsing by wildlife or livestock. This will be especially important for oak species that have recently experienced broadscale declines in regeneration and establishment, such as blue oak, Oregon white oak, black oak, and valley oak. Additional oaks can be planted in bare areas caused by fire suppression (such as bulldozer lines) by directly sowing acorns (see McCreary 2009 in references section for information on planting acorns).

Landowners who want to return severely burned mixedconifer forests to a forested condition may need to consider planting conifer seedlings. Planting is a given for landowners who want to re-establish a timber basis on their landscape in an efficient manner. For landowners with more general landscape quality or wildlife habitat goals, planting conifers generally may still be useful in very large patches of high-severity fire, where live trees that provide seed for the next generation are absent. Even where live trees are nearby, natural regeneration of trees may take decades, because the early pioneering conifer seedlings must compete with vigorous shrubs for resources. Planting and shrub control may be needed for conifer re-establishment.

\section{Conifer planting}

Site preparation. It is crucial to properly prepare the site before planting new trees. This often involves removing or burning the residue from the previous harvest or fire, ripping the soil to break soil compaction, and controlling weeds and competing brush. Salvage harvesting with thorough cleanup of slash usually prepares a site adequately for planting. For more information on site 


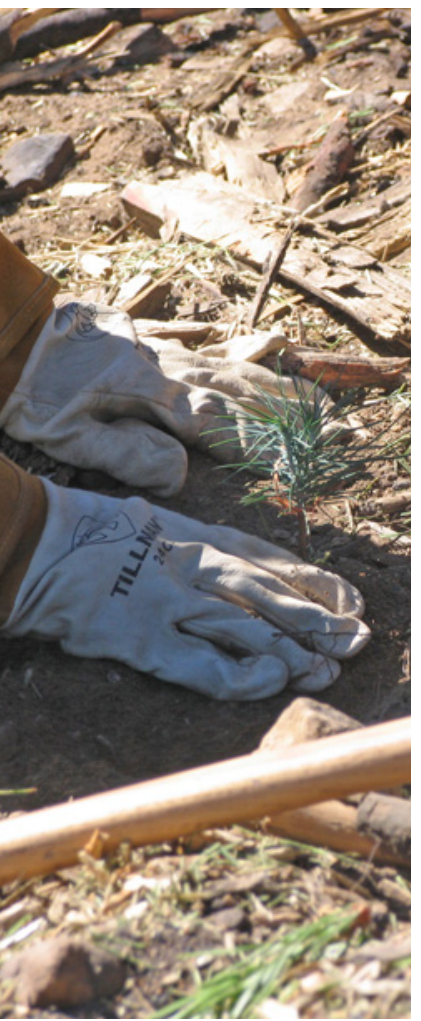

One-year-old seedling planted in a burned area with masticated material (mulch) around it. Photo: S. Kocher. preparation and tree planting, see Forest Stewardship Series 7 on forest regeneration (UC ANR Publication 8237).

Selecting tree species. Selecting the appropriate tree species for the site is also important. Ponderosa pine is best suited for planting in exposed, open, low-to-mid-elevation mixed-conifer sites created by a high-severity wildfire. In the Sierra Nevada, Douglasfir, sugar pine, incense-cedar, and white fir are less successful on exposed sites but will successfully become established under the shadier conditions of low- and moderate-severity fires, which leave more of the original forest stand intact. In the Coast Range, Douglas-fir can be planted in the sites with little canopy cover, but it may benefit from being planted behind a rock or log that can provide some shade. Deep, nongravelly soils with good moistureholding capacity regenerate Douglas-fir, sugar pine, and white fir if competing vegetation is controlled. Redwoods, which resprout after being top-killed, rarely need to be replanted.

It is important to consider the genetic stock of the seedlings you are planting. State law currently requires planting seedlings from the same seed zone as the planting site. A seed zone is an area with similar physical and climatic characteristics with trees that are adapted to the site and able to survive conditions there. When an exact match is not available, there are rules for how to choose seed from nearby zones. In light of the warming climate, foresters are experimenting with planting seedlings from seed zones that have slightly warmer and drier conditions in anticipation of future climate change effects. However, until solid research results are available, choosing seeds from different seed zones should only be done in consultation with a registered professional forester (RFP) (see the resources section for more information). Planting species totally novel to the site is not recommended, as their success and vigor in a local area has not been evaluated, and they may be vulnerable to pest and disease issues.

Planting seeds directly is not recommended due to the overwhelming loss of seeds from animal and insect predation. Finding young seedlings to plant is more difficult than previously, since the nursery capacity in California has decreased in recent years. Landowners will need to contact reputable nurseries to order the desired number of seedlings of each desired species. Private nurseries may require a contract to grow the seedlings, which is put in place at least a year in advance of when they are needed for planting. Some may have a requirement for a minimum quantity of seedlings. Nursery-grown seedling stock can be ordered as 1-yearold container stock or 2-year-old bare-root stock. Your RPF can help you identify where to buy seedlings.

Seedling care. Seedlings are vulnerable to grasshoppers, weevils, gophers, rabbits, mice, deer, and cattle. Seedling protectors are available to prevent damage from deer and cattle. Controlling grass and the vigorous shrub response can help alleviate the insect and rodent problem and may also be necessary to ensure tree survival, especially on poorer soils and harsher sites, where competition is great for available moisture and nutrients. Weed control is most effective and cheapest when done within the first 2 to 3 years following planting. If delayed or postponed altogether, trees may die or languish.

Seedling growth may be limited by competing vegetation. Management of the competing vegetation may be necessary to support seedling survival. Weed control gives trees a few years' advantage over competing vegetation, allowing trees to predominate on the site once again. In intensively managed ponderosa pine stands on good timber sites, merchantable trees 20 inches (about $50 \mathrm{~cm}$ ) in diameter and 100 feet (about $30 \mathrm{~m}$ ) tall can be produced in 60 to 80 years. On poor sites with uncontrolled competition, conifer dominance might take 50 years or more, with merchantable trees produced in 100 years or more. For more information, see Forest Stewardship Series 6 (UC ANR Publication 8237) on forest vegetation management.

Reforestation cost-share and assistance programs. A number of cost-share programs are available to assist landowners with reforestation and other resource conservation practices. Examples are the California Forest Improvement Program (CFIP) and other reforestation assistance programs administered by CAL FIRE and the Environmental Quality Program (EQIP) administered by the USDA Natural Resources Conservation Service (NRCS). Available programs will vary by county, the resources available to the 
agency that year, the size and status of your forested land, and your management goals. Agencies that provide technical assistance and administer cost-share programs are listed in the resources section near the end of this publication.

\section{Soil Erosion}

Soil erosion is one of the biggest concerns postfire, because physical changes to the soil and the loss of understory vegetation cover from a severe fire can lead to significant soil erosion, increased water runoff, mudflows, and life-threatening debris flows. Erosion can lead to loss of soil nutrients and increased sediment yields in local waterways. These, in turn, can result in flooding, over-flowing culverts, and damaged roads and structures. The highest erosion rates typically occur in the first year postfire, since erosion risk decreases significantly through time as vegetation re-establishes and litter accumulates, eventually stabilizing the soil. Given the potential for significant effects in that first year or two, decisions about erosion control treatments will need to be made fairly quickly, before the winter rains come. Assessing the level of fire severity effects on the soils and vulnerability to erosion immediately after the fire is important.

\section{Soil Erosion Assessment}

Postfire erosion depends on characteristics of the local landscape and the patterns of burning. Erosion potential is highest on steep slopes and long hillslope flow paths that have experienced high fire severity. In addition to consuming live vegetation, severe fires can also alter the physical properties of the soil. High soil burn severity can burn and volatilize organic material and nutrients in the soils, which then form a waxy layer that repels water. The reduced water infiltration in the top few inches of soil increases rainwater runoff, soil erosion, downstream sedimentation, and debris flows. The presence and degree of repellency vary widely across burned landscapes, even within high-severity areas. In addition to burn severity, the soil type is also an important predictor for erosion. Silt, very fine sand, and some clay-textured soils tend to be more erodible than sand, sandy loam, and loam soils. Vegetation burn severity is generally a less important predictor than how severely the soil was burned, but low and moderate vegetation burn severity are less likely to erode, because they are more likely to have maintained some live vegetation or litter cover.

\section{Severely Burned Soils: Assessing Soil Repellency}

\section{The Water Drop Penetration Test}

This is the simplest way to obtain a general measure of soil repellency in severely burned soils. Because the degree and spatial distribution of repellency can vary widely, it is important to conduct several drop tests at an individual site, across many different sites that are at high risk of increased runoff and erosion.

You will need

$$
\text { - a dropper, water, a stopwatch, and a notebook }
$$

How to do it:

Find a place in your notebook to take notes on the results for each test for each area. Take the water dropper and drop one droplet onto the soil surface and start the timer. Watch the drop and record how many seconds it takes to penetrate the soil surface. Average your results for each site you visit and evaluate its repellency.

- wettable or non-water repellent $(<5$ seconds)

- slightly repellant (5-60 seconds)

- strongly repellant (60-600 seconds)

- severely repellant (600-3,600 seconds)

- extremely water repellent ( $>3,600$ seconds)

Repeat this test at a few different soil depths by scraping away some soil after each test is complete. This field-assessment technique is not a perfect assessment of repellency, but it is generally adequate to estimate repellency and can be done by a nonscientist for low cost. Other techniques are more accurate and require specialized equipment and training. If you have serious concerns about your soil, you should consult with a registered professional forester or a soil scientist to conduct a more accurate assessment.

Source: Adapted from Dekker and Ritsema 1994. 


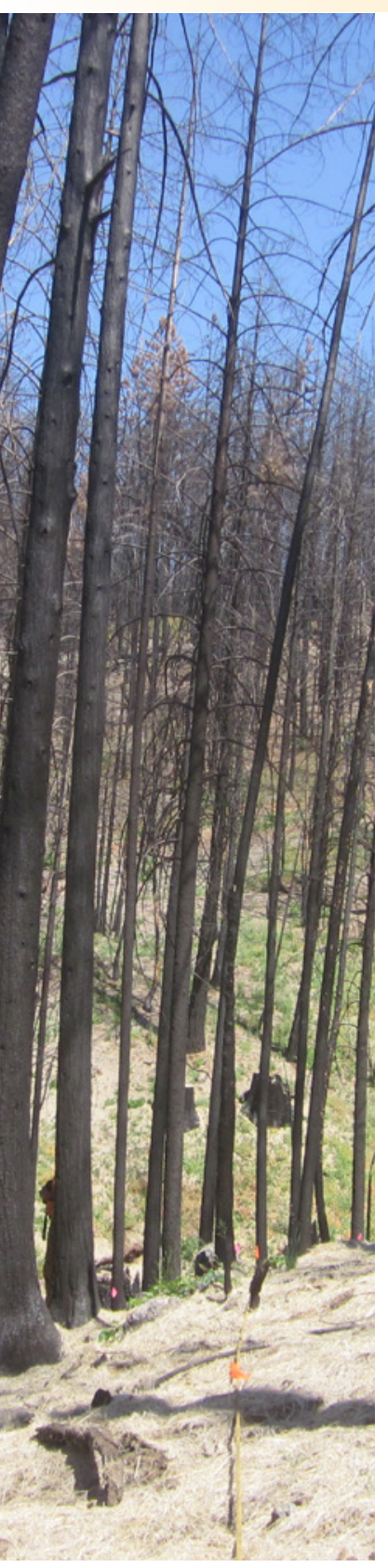

Straw mulch spread across a slope burned by the 2013 Rim fire in Stanislaus National Forest. The mulch is used to protect the soil from erosion caused by rain. Photo: K. Shive.
The final major determinant of erosion potential is the general pattern of rainfall in your region. The greatest erosion is produced in intense, short-duration rainstorms; it only takes one large rainfall event following a severe fire to create erosion problems. The largest erosion and runoff events occur when a major, high-intensity rainfall event occurs after a large, severe fire.

\section{Soil Erosion Mitigation Options}

\section{Seeding}

In the past, seeding flowering plants and grasses to speed up vegetation establishment and therefore soil stability was one of the most common approaches to addressing soil erosion on federal lands. However, many studies across the West over the last several decades show that, despite the expense, it generally does not increase the cover above what regenerates naturally and has little effect on erosion. Furthermore, despite the use of certified weedfree seed mixes, the practice has been repeatedly linked with the introduction of non-native species. For these reasons, seeding for erosion control is not recommended.

\section{Contour log felling}

Contour log felling is the practice of cutting dead trees and placing them on the contour of the slope, with a reservoir area on the uphill side to catch eroding soil. This does not stop the erosion from occurring, but instead catches some of the eroded soil at various points on the hillside, thereby reducing the amount that ends up in streams. This practice works for small rain events, but is less successful for larger rain events. Furthermore, its efficacy highly depends on how well the logs are installed. They must be long enough ( 15 to 20 feet long), accurately placed along the contour, and installed at a high enough density, with soil berms installed at the end of the logs. For more detailed information on how to use this technique properly, see the resources section.

\section{Mulch}

The best available science to date indicates that spreading mulch across the landscape is the most effective erosion control treatment because it provides what high-severity fire removed-ground cover. This ground cover allows water to infiltrate the soil rather than run off and erode the soil. It also increases soil moisture and mitigates soil temperature fluctuations, which protects regenerating vegetation. There are many different types of mulches, but these are generally of two kinds: wet and dry. Wet mulches (also known as "hydromulch") mix components with water to form a slurry that is applied to the soil surface. These can also have seeds in the mix. Wet mulches are not considered as effective as dry mulches on longer slopes, because they do not hold up well against concentrated flow. On shorter slopes, they may be useful, but the selection of tackifier (the "glue" of the slurry) is complicated, as they all have different costs, performance characteristics, and environmental effects, many of which are difficult to discern due to the proprietary nature of the products.

Dry mulches include straw mulch and wood mulch, such as wood chips, wood shreds, and wood strands (thin wood strips manufactured from nonmerchantable timber or production waste). Wood mulches can be made from local, site-specific forest materials, including burned trees on-site, shredded debris from forest clearing, or thinned, unburned trees from hazardous fuel reduction. Using local materials can reduce the cost and time for transport, and larger wood chippers and shredders may be able to handle burned logs, which may increase the potential to use on-site materials.

Straw mulch has high efficacy in reducing rainwater runoff, soil erosion, and downstream sedimentation when the mulch covers 60 to 80 percent of the soil surface. Drawbacks to mulch application include the time and expense involved and the potential to introduce non-native species, even when certified weed-free straw is used. Rice straw has been proposed as a safe alternative to wheat straw, because the weeds of a wet rice field were thought unlikely to germinate in mixed-conifer forest habitat. However, several non-native species, including a noxious weed, were introduced through rice mulch on recent wildfires in central California. Given its efficacy in erosion control, mulch is still a good choice in areas at high risk of erosion, but it should be accompanied by monitoring for non-natives and treatments if necessary. 


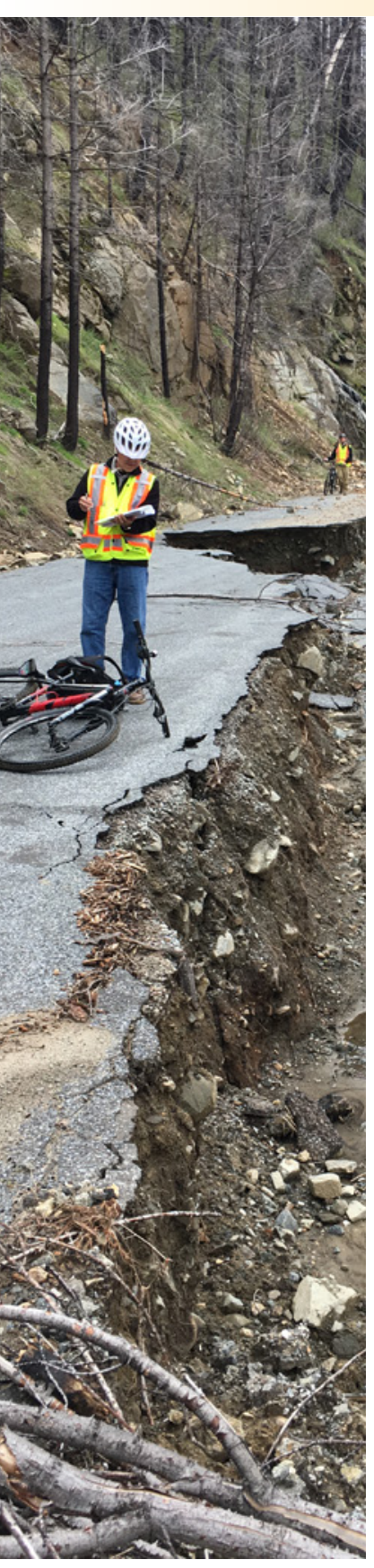

Road damage from postfire soil erosion that occurred in a severely burned area after heavy winter rains. Photo: Vincent Pacific.
These erosion control treatments vary widely in terms of cost and application time. Average cost estimates for treating large landscapes, such as federally owned land, show that contour felling logs is the least expensive per acre and mulching is the most expensive. However, to date there are no comparisons for costs for smaller, private parcels. The cost differences per acre between treatments will vary by the amount of land to be treated, access routes, costs of certified, seed-free mulch, and availability of heavyequipment contractors. We recommend that landowners first consider where and how much of their property may need treatment, review the overall pros and cons of different treatments, and then obtain cost estimates for their preferred treatment approaches.

\section{Road Protection}

Roads may have been damaged by the fire. Wildfire can burn buried wood in the fill base and plastic culverts. Following a wildfire, it is highly recommended to conduct a complete road survey to assess the condition and function of the road and its drainage systems. Additionally, surveys are suggested during the winter period because logs, branches, and sediment can be washed down and plug culverts or ditches. Furthermore, the drainage system of roads in a burned area may not be adequate to handle the increased runoff, debris, and sediment after a fire. Roads and trails can also act as conduits for the increased surface flow and may need extra attention to slow water movement. Where fire control lines were constructed, make sure that proper drainage features have been established and are functioning.

\section{Road Assessment}

A road beneath a severely burned slope that is steep or has a long flow path for water, or that crosses a severely burned drainage, is a candidate for mitigation measures.

\section{Road Mitigation Options}

To protect the road system as well as the downstream water quality, consider taking the following measures. To insure proper design and installation, work with experienced professionals.

To protect the road system:
- Armor culvert inlets or bridge abutments.

- Patrol roads during significant rain events to clean out clogged ditches and culverts.

To slow and divert water:

- Construct rolling dips or waterbars for limited-use roads.

- Evaluate road shape and remove berms on the outside edge of the road's driving surface to allow dispersal of water.

To trap sediment and debris:

- Install sediment traps below culverts to prevent sediment from leaving the site.

- Install trash racks at culvert inlets to block woody debris from plugging the culvert. These will need to be regularly checked for debris and cleared if necessary.

To increase drainage:

- Enlarge the current ditch system.

- Replace damaged culverts or install larger culverts where debris flows are likely to exceed existing capacity.

Increasing drainage capacity on roads is the most expensive treatment, whereas patrolling during rainstorms, though time intensive, is the least expensive. For more information, see the road management publications listed in the resources section.

\section{Hazard Tree Removal}

Hazard tree removal is the removal of individual dead trees or fire-weakened trees that are at risk of falling on people, structures, trails, or roadways. The primary goal of hazard tree removal is safety. Dead trees that threaten homes and roads should be removed as soon as possible after the fire. Trees that have been substantially damaged, with little green canopy and high levels of bark char, are at higher risk for death in the near future, and so it is more efficient to remove these at the same time as dead trees are removed. Some property owners may want to retain trees they feel have a chance of recovery. In such cases, the opinion of a licensed arborist or RPF on the likelihood of tree recovery may be useful, although tree mortality can sometimes be difficult to predict, even 


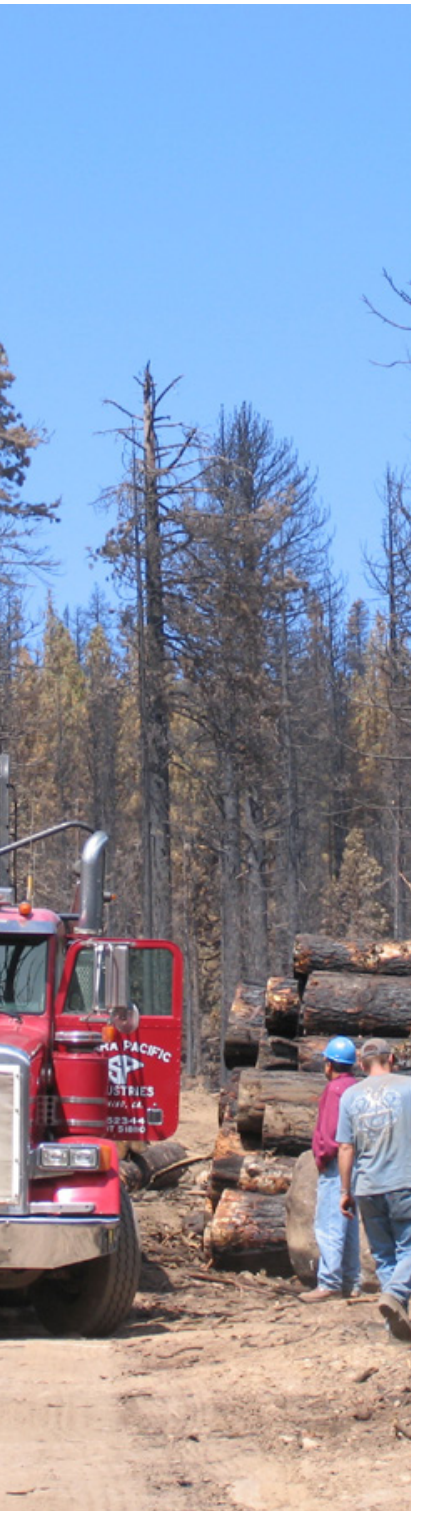

Salvage harvesting after the 2007 Angora fire. Photo: S. Kocher. for professionals. Whether to keep or remove a tree is a matter of opinion and depends on the values at risk in the path of potential tree fall.

\section{Salvage Harvest}

Salvage harvests, or salvage logging, describes the removal of trees that were killed in the fire in order to recover economic value that would otherwise be lost. Salvage must occur relatively quickly postfire because the dead or damaged trees begin to decay and lose value after the first 6 to 12 months. Some of that economic return can be used to fund erosion control or reforestation efforts. Landowners may also salvage logs as part of a broader program to hasten reforestation. Many landowners do not want to invest in planting in an area likely to be dominated by heavy surface fuels in the future or where falling snags could damage the planted seedlings and residual trees.

Like any management treatment, salvage logging has many effects on the landscape that will play out over decades. First, salvage logging affects dead and downed fuels in both the shortand long-term in contrasting ways. Any limbs and tops of trees left behind by logging increases fine surface fuels compared with unlogged, burned stands, which in turn increase fire risk in the short-term. However, in the long-term, salvaged stands have less large-diameter fuel on the ground because standing dead trees will eventually fall and accumulate as new surface fuel. When these large-diameter fuels left in unsalvaged stands burn in the next wildfire, they smolder for some time, resulting in sustained, lethal soil temperatures that can destroy seeds in the seed bank and important nutrients.

A salvage operation, like all forest management, should be conducted carefully and thoughtfully. For example, use of heavy equipment, when not done carefully, can lead to soil compaction. On the other hand, equipment can be used to rip the soil, which decompacts it and increases water infiltration. The risks are higher when salvage logging is conducted on steep slopes or in compactible soils. Use of heavy equipment also can increase the chances of nonnative species introduction. Removing all dead trees reduces wildlife habitat and future coarse, woody debris on the ground, which is important for nutrient cycling and water storage. Finally, where natural regeneration is already occurring, the heavy equipment is likely to damage or crush tiny seedlings. However, if replanting is planned anyway, this may not be a problem. A salvaging plan must be developed in consultation with an RPF, who will help develop the harvesting strategy and ensure mitigations to avoid causing negative impacts.

\section{Tree Mortality Assessment}

As mentioned above, the decision to log postfire mostly depends on your objectives for your landscape, market conditions, and concerns about the safety of life and property. Once that decision is made, you can assess individual trees for mortality and risk of mortality, to inform you about which trees to remove. Keep in mind that the value of the wood decreases significantly as time passes after the fire, and thus the decision to salvage should be made quickly. Permits are available to streamline the process following a wildfire.

\section{Tree Mortality Mitigation Options}

Salvage operations can include complete or partial harvests of all merchantable trees. The number of trees to cut or leave will depend on your objectives, your plans for reforestation, and whether or not your roads are in good enough condition to support the harvest operation. Landowners should consider leaving behind some dead trees for wildlife habitat. The forest roads will need to meet current regulatory standards at the time of harvest. The market and local mill capacity will also play a role in the amount of wood that can be harvested and delivered to a mill. The distance to a mill is likely the greatest determinant of the economic profitability or cost of the operation. With the rise of large fires and increased tree mortality in some regions of California, many mills are continually operating at maximum capacity, which means they often do not have the capacity to buy logs from smaller landowners. This greatly reduces the ability of landowners in those regions to remove dead trees in a cost-effective manner. All harvest operations should include mitigations for potential non-native species introductions from equipment. 
If you choose to harvest some of the trees killed by fire, you will need to acquire the proper permits. You must notify the California Department of Forestry and Fire Protection (CAL FIRE), which regulates timber harvest on private land in California. Unlike harvesting done when there is no fire, salvaging of firekilled trees does not require a timber harvest plan (THP). It does, however, require that you file either a Notice of Emergency Timber Operations or a Notice of Exemption. The exemption notice may be filed by the landowner directly, when heavy equipment use is limited and less than 10 percent of merchantable trees will be removed. The emergency notice must be signed by a registered professional forester, who certifies that an emergency exists. Only trees that are dead or likely to die within 1 year because of the emergency may be harvested. Both require a waiting period before operations may begin and compliance with other regulations aimed at protecting water quality, soil conditions, cultural resources, and riparian habitat.

\section{Making Use of Professional Help}

A registered professional forester (RPF) can help you implement a strategy to meet your objectives for your land. An RPF can help you sell trees, secure the best price for them, plan and execute the harvest, and reforest your land. Asking neighbors and friends who have harvested timber before is a good way to find RPFs. You can also search the internet or consult most telephone yellow pages under "Forester, Consultant." See Forest Stewardship Series 24 (UC ANR Publication 8254) on accessing professional help (referenced in the resources section).

You may want to contact several foresters to obtain estimates for the services you want provided. Typically, there is no charge for an estimate. You will need to develop a written contract with the forester that spells out the services being provided and fees being charged. Following a wildfire, landowners may receive unsolicited offers for their burned trees. Give serious consideration to obtaining independent assessments of your timber value. You can do this by getting an estimate from your own forester rather than relying on estimates provided by foresters or loggers working for sawmills.
Services to seek from a registered professional forester.

Registered professional foresters can offer a wide variety of services to landowners after wildfire. These include

- helping assess your goals and options

- preparing an emergency notice or timber harvest plan

- assessing fire-damaged trees

- marking trees to be harvested and those to be left behind for wildlife habitat

- establishing cutting boundaries

- obtaining archaeological clearance

- obtaining necessary permits from the California Department of Fish and Wildlife (for culvert and stream-crossing work) and Caltrans permits

- providing an estimate of timber volume by species

- calculating the timber basis for casualty loss and tax purposes

- finding a licensed timber operator or logger

- supervising the logging operation

- giving advice on reforestation

- giving advice on erosion control

For erosion control, in addition to getting advice from an RPF, landowners should enquire to see if an assessment is being done on their watershed by a federal agency (typically the Natural Resources Conservation Service). If you share a watershed with federal land, an additional resource is the Burned Area Emergency Response Team reports conducted by the U.S. Forest Service. These reports are put together on larger federal fires and often rely on a watershed assessment. You can find out what is being done by consulting agency web pages or local offices.

\section{TAX IMPLICATIONS}

A loss of a portion of the forest stand on your property due to wildfire can be claimed on your federal income tax statement as a casualty loss. A casualty loss is a sudden and unanticipated loss resulting from fire, storm, or other natural disasters. In general, casualty losses can be deducted directly from ordinary income. 
Getting tax advice. When planning for tax implications of fire losses, you should strongly consider getting tax advice from an enrolled agent. An enrolled agent can help you evaluate your tax situation and advise you on the most tax-advantageous method for selling burned timber. An enrolled agent can also compute your taxes for you. Enrolled agents can be found by consulting local telephone book yellow pages under "Tax Preparation" or searching online. The discussion that follows is based on tax law current in the year 2016.

Allowable deduction. Calculating the amount that can be claimed as a deduction requires sound data on your forest stand, best collected by a registered professional forester. In some cases, the expense of collecting the necessary data may be greater than the tax savings. However, the data required to determine casualty loss can be collected by a registered professional forester while simultaneously developing a salvage harvest program.

The allowable deduction is the lesser of one of the following two values:

- The change in the fair market value of the timber that resulted from the fire. In order to determine this value, an accurate inventory of the volume, grade, and size class of the timber both before and after the fire is required. Since landowners may not have a thorough assessment of their timber stand before a fire, an estimate of its previous condition is required, along with knowledge of timber and land values.

- The adjusted basis of the timber. The original timber basis is defined as the original purchase price for the timber asset. When timbered property is purchased, inherited, or received as a gift, the value of the entire property is allocated to the land, the improvements on the land, and the value of the timber itself. This value is adjusted over time when capital additions are made or when the amount of the timber basis is depleted, as during a wildfire or timber harvest. If the basis has not been calculated previously, the adjusted basis of timber can be calculated retroactively with an estimate of the timber volume, grade, and market value at the time of purchase of the property. The longer the timberland has been owned, the more difficult and costly it becomes to make an estimate of the basis.
Yield tax. If you do decide to salvage harvest some of your burned timber, just like when you harvest unburned timber, you will be required to pay a yield tax to the California State Board of Equalization. This is based on the value of the timber just before it is harvested. The tax rate is calculated annually, and in 2016 the rate was 2.9 percent. See the resources section for the California State Board of Equalization website.

Reforestation tax credit. If you decide to replant burned areas, 2016 federal tax laws allowed you to deduct up to a maximum of $\$ 10,000$ in reforestation-related expenses per tax year per qualified timber property. Expenses exceeding $\$ 10,000$ in a tax year may be amortized over a 7-year period. Check with the federal IRS and California Franchise Tax Board for current allowances.

\section{Resources}

For more information on forest stewardship in California, see the 24-part Forest Stewardship Series (UC ANR Publication 8323) available online at the ANR Catalog website, anrcatalog.ucanr.edu. The following sources can provide more information on the topics in this publication.

\section{General Information}

University of California Cooperative Extension Forestry Advisors. The local office can be found in many telephone directories under "Government Listings, County Government Offices, Farm Advisor (or University of California Cooperative Extension). Information is also available at the UC ANR Forest Research and Outreach website, ucanr.edu/forestry/.

California Forest Stewardship Helpline. Phone: 1-800-738-8733.

To find a registered professional forester (RPF), consult the current roster of licensed foresters on the CAL FIRE website, http://www.fire.ca.gov/. One version of the list is organized by county to help locate RPFs in your area (see the Board of Forestry and Fire Protection website, bofdata.fire.ca.gov/ professional_foresters_registration/). 
Forest Stewardship Series 24 (UC ANR Publication 8254), Professional Assistance. ANR Catalog website, anrcatalog. ucanr.edu/pdf/8254.pdf/.

\section{Cost-Sharing and Technical Assistance}

Forest Stewardship Series 23 (UC ANR Publication 8253), Technical and Financial Assistance. ANR Catalog website, anrcatalog.ucanr.edu/pdf/8253.pdf/.

California Department of Forestry and Fire Protection (CAL FIRE). The local office can be found in many telephone directories under "Government Listings, State Government Offices, Forestry and Fire Protection." Also available online at the CAL FIRE website, www.fire.ca.gov.

U.S. Department of Agriculture, Farm Services Agency (FSA). The local office can be found in many telephone directories under "Government Listings, United States Government Offices, Agriculture, Dept. of, Farm Services Agency." Also available online at the USDA Farm Service Agency website, www.fsa.usda.gov.

U.S. Department of Agriculture, Natural Resources Conservation Service (NRCS). The local office can be found in many telephone directories under "Government Listings, United States Government Offices, Agriculture, Dept. of, Natural Resources Conservation Service." Also available online at the USDA Natural Resource Conservation Service California website, www.ca.nrcs.usda.gov.

\section{Fire Regimes and Fuels Management}

Forest Stewardship Series 15 (UC ANR Publication 8245), Wildfire and Fuel Management. ANR Catalog website, anrcatalog.ucanr.edu/pdf/8245.pdf.

\section{Forest Harvesting and Regulations}

Forest Stewardship Series 19 (UC ANR Publication 8249), Laws and Regulations Affecting Forests Part 1: Timber Harvesting. ANR Catalog website, anrcatalog.ucanr.edu/pdf/8249.pdf.
California Department of Forestry and Fire Protection (CAL FIRE). Emergency Exemptions and Timber Harvest Plans. See above.

\section{Forest Landowner Assistance}

Forest Landowners of California. Phone: (916) 972-0273. Forest Landowners of California website, www.forestlandowners.org.

Resource Conservation Districts (RCDs). Phone: (916) 447-7237. California Association of Resource Conservation Districts website, www.carcd.org.

\section{Invasive Species}

UC Forest Stewardship Series 6 (UC ANR Publication 8236), Forest Vegetation Management. ANR Catalog website, anrcatalog.ucanr.edu/pdf/8236.pdf.

Forest Stewardship Series 14 (UC ANR Publication 8236), Exotic Pest Plants. ANR Catalog website, anrcatalog.ucanr.edu/ pdf/8244.pdf.

University of California, Integrated Pest Management Program. UC IPM website, www.ipm.ucdavis.edu/PMG/PESTNOTES/ pn74139.html.

California Invasive Plant Council. For general invasive plant information, see the California Invasive Plant Council website, www.cal-ipc.org.

\section{Planting and Regeneration}

Forest Stewardship Series 7 (UC ANR Publication 8237), Forest Regeneration. ANR Catalog website, anrcatalog.ucanr.edu/ pdf/8237.pdf.

Forest Regeneration Starts with the Seeds. California Forestland Steward Newsletter. Winter 2013. California Forest Stewardship Program website, http://calfire.ca.gov/ foreststeward/pdf/news-winter2013.pdf.

The Forest Seedling Network. This is an interactive website connecting forest landowners with seedling providers and forest management services and contractors. Forest Seedling Network website, http://www.forestseedlingnetwork.com/. 


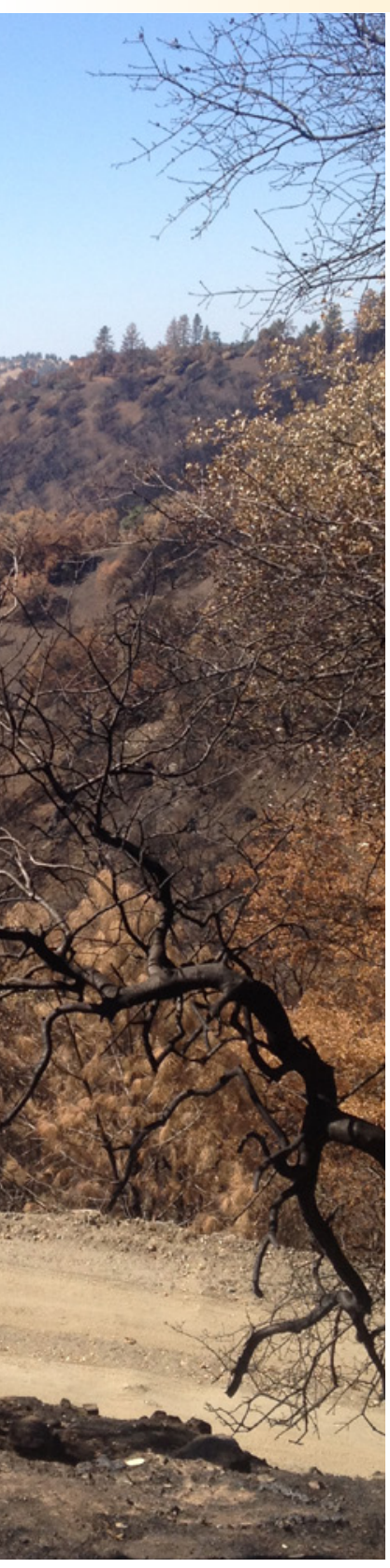

A forest road where the 2014 Sand fire burned directly above and below. The road system should be assessed after a fire to identify any increase in soil erosion potential. Photo: S. Kocher.

\section{Road Management}

Forest Stewardship Series 17 (UC ANR Publication 8247), Forest Roads. ANR Catalog website, anrcatalog.ucanr.edu/pdf/8247.pdf.

Rural Roads: A Construction and Maintenance Guide for California Landowners. ANR Catalog website, anrcatalog. ucanr.edu/pdf/8262.pdf.

\section{Tax Treatment of Timber}

California Board of Equalization website, www.boe.ca.gov/ proptaxes/timbertax.htm.

National Timber Tax website. Contact them at the National Timber Tax website, https://timbertax.org/.

\section{Tree Survival}

Burned Oaks: Which Ones Will Survive? ANR Catalog website, anrcatalog.ucanr.edu/pdf/8445.pdf.

\section{References}

Agee, J. K. 1996. Fire ecology of Pacific Northwest forests. Washington, DC: Island Press.

Cal-IPC. 2012. Preventing the spread of invasive plants: Best management practices for land managers. 3rd ed. Berkeley: California Invasive Plant Council. California Invasive Plant Council website, http://www.cal-ipc.org/ip/prevention/ PreventionBMPs_LandManager.pdf.

DeBano, L. F. 1981. Water repellent soils: A state-of-the-art review. Gen. Tech. Rep. GTR-PSW-46. Berkeley, CA: U.S. Department of Agriculture, Forest Service, Pacific Southwest Forest and Range Experiment Station. U.S. Forest Service website, www.treesearch.fs.fed.us/pubs/26997.
Dekker, L. W., and C. J. Ritsema. 1994. How water moves in a water repellent sandy soil: Potential and actual water repellency, Water Resources Research 30(9): 2507-2517.

McCreary, D. D. 2009. Regenerating rangeland oaks in California. Oakland: University of California Division of Agriculture and Natural Resources Publication 21601e. ANR Catalog website, anrcatalog.ucanr.edu/pdf/21601e.pdf.

Napper, C. 2006. Burned area emergency response treatments catalog (BAERCAT). 0625 1801P. San Dimas, CA: USDA Forest Service, San Dimas Technology and Development Center. USDA Forest Service website, www.fs.fed.us/t-d/pubs/ pdf/BAERCAT/lo_res/06251801L.pdf

Parson, A., P. R. Robichaud, S. A. Lewis, C. Napper, and J. T. Clark. 2010. Field guide for mapping post-fire soil burn severity. U.S. Forest Services website, http://www.treesearch. fs.fed.us/pubs/36236.

Robichaud, P. R., L. E. Ashmun, and B. D. Sims. 2010. Post-fire treatment effectiveness for hillslope stabilization. U. S. Forest Service website, http://www.treesearch.fs.fed.us/pubs/35691.

Robichaud, P. R., J. L. Beyers, and D. G. Neary. 2000. Evaluating the effectiveness of postfire rehabilitation treatments. U.S. Forest Service website, http://www.treesearch.fs.fed.us/ pubs/4571.

Sugihara, N. G., J. van Wagtendonk, J. Fites-Kaufman, A. E. Thode, and J. K. Agee, eds. 2006. Fire in California's ecosystems. Berkeley: University of California Press.

\section{ACKNOWLEDGMENTS}

This publication is an updated version of the 1999 ANR Publication 8386, authored by Susan Kocher, UCCE Forestry Advisor, and Richard Harris and Gary Nakamura, UCCE Forestry Specialists in the Department of Environmental Science, Policy, and Management at the University of California, Berkeley. 


\section{FOR MORE INFORMATION}

To order or obtain ANR publications and other products, visit the ANR Communication Services online catalog at http://anrcatalog.ucanr.edu/ or phone 1-800-994-8849. You can also place orders by mail or FAX, or request a printed catalog of our products from

University of California

Agriculture and Natural Resources

Communication Services

1301 S. 46th Street

Building 478 - MC 3580

Richmond, CA 94804-4600

Telephone 1-800-994-8849

510-665-2195

FAX 510-665-3427

E-mail: anrcatalog@ucanr.edu

(02017 The Regents of the University of California. This work is licensed under the Creative Commons Attribution-NonCommercial-NoDerivatives 4.0 International License. To view a copy of this license, visit http://creativecommons.org/licenses/by-nc-nd/4.0/ or send a letter to Creative Commons, PO Box 1866, Mountain View, CA 94042, USA.

Publication 8386

ISBN-13: 978-1-60107-981-7

Revised edition, July 2017

The University of California, Division of Agriculture and Natural Resources (UC ANR) prohibits discrimination against or harassment of any person in any of its programs or activities on the basis of race, color, national origin, religion, sex, gender, gender expression, gender identity, pregnancy (which includes pregnancy, childbirth, and medical conditions related to pregnancy or childbirth), physical or mental disability, medical condition (cancerrelated or genetic characteristics), genetic information (including family medical history), ancestry, marital status, age, sexual orientation, citizenship, status as a protected veteran or service in the uniformed services (as defined by the Uniformed Services Employment and Reemployment Rights Act of 1994 [USERRA]), as well as state military and naval service.

UC ANR policy prohibits retaliation against any employee or person in any of its programs or activities for bringing a complaint of discrimination or harassment. UC ANR policy also prohibits retaliation against a person who assists someone with a complaint of discrimination or harassment, or participates in any manner in an investigation or resolution of a complaint of discrimination or harassment. Retaliation includes threats, intimidation, reprisals, and/or adverse actions related to any of its programs or activities.

UC ANR is an Equal Opportunity/Affirmative Action Employer. All qualified applicants will receive consideration for employment and/or participation in any of its programs or activities without regard to race, color, religion, sex, national origin, disability, age or protected veteran status.

University policy is intended to be consistent with the provisions of applicable State and Federal laws.

Inquiries regarding the University's equal employment opportunity policies may be directed to: John Sims, Affirmative Action Contact and Title IX Officer, University of California, Agriculture and Natural Resources, 2801 Second Street, Davis, CA 95618, (530) 750-1397. Email: jsims@ucanr.edu. Website: http://ucanr.edu/sites/anrstaff/Diversity/Affirmative_ Action/.

An electronic copy of this publication can be found at the ANR Communication Services catalog website, http://anrcatalog.ucanr.edu/.

UChis publication has been anonymously peer reviewed for technical accuracy REVIEWED by University of California scientists and other qualified professionals. This and Freshwater Resources Bill Stewart.

rev-07/17-LR/CR 